

\section{Sumário}

Editorial

Mariela Morales Antoniazzi, Flávia Piovesan e Patrícia Perrone Campos Mello

I. Parte Geral

1. Constitucionalismo transformador: IUS Constitutionale Commune Na

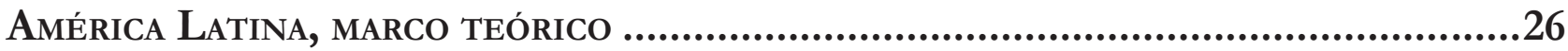

CONSTITUCIONALISMO TRANSFORMADOR INTERNACIONAL NA AMÉRICA LATINA......................28 Armin von Bogdandy e René Urueña

INTERDEPENDÊNCIA E INDIVISIBILIDADE DOS DIREITOS HUMANOS: UM NOVO OLHAR PARA A PANDEMIA DE Covid-19. .75

Flávia Piovesan e Mariela Morales Antoniazzi

DirEITOS HUMANOS EM TEMPOS DE EMERGÊNCIA: UMA PERSPECTIVA INTERAMERICANA COM especial foco na Defesa do Estado de Direito .95

Christine Binder

Monitoramento, PERSUASÃo E PROMOÇão do diálogo: QUAL O PAPEL DOS ORGANISMOS SUPRANACIONAIS DE DIREITOS HUMANOS NA IMPLEMENTAÇÃO DE DECISÕES INDIVIDUAIS?

Clara Sandoval, Philip Leach e Rachel Murray

REPENSANDO AS DERROGaÇÕES AOS TRATAdOS DE DiREITOS HUMANOS 142 Laurence R. Helfer

\section{ResiliÊNCIA DEMOCRÁtica: CoNTRIBUiçÕes do CONSTITUCIONALISMO}

TRANSFORMADOR CONTRA O RETROCESSO

A COMISSÃo INTERAMERICANA DE DiREITOS HUMANOS COMO WATCHDOG DEMOCRÁTICO: DESENVOLVENDO UM SISTEMA DE ALERTA PRECOCE CONTRA ATAQUES SISTÊMICOS...................169 Patrícia Perrone Campos Mello, Danuta Rafaela de Souza Calazans e Renata Helena Souza Batista de Azevedo Rudolf

Erosão democrática e a Corte InTeramericana de direitos humanos: o caso VENEZUELANO 196

Roberto Dias e Thomaz Fiterman Tedesco

ParticipaÇão política no Constitucionalismo latino-americano: uma ComparaÇão com o MODELO BRASILEIRO. 226 Júlio Grostein e Yuri Novais Magalhães 


\section{REFUNDAÇÃo DEMOCRÁtICA CONTRIBUIÇÕES DO CONSTITUCIONALISMO}

TRANSFORMADOR A UMA NOVA ORDEM CONSTITUCIONAL

LOS DERECHOS SOCIALES Y EL CONSTITUCIONALISMO TRANSFORMAdOR EN CHILE .251

Gonzalo Aguilar Cavallo

La aplicación del Derecho internacional de los derechos humanos en Chile: DIAGNÓSTICOS Y PROPUESTAS PARA UNA NUEVA CONSTITUCIÓN TRANSFORMADORA .275

Pietro Sferrazza Taibi, Daniela Méndez Royo e Eduardo Bofill Chávez

Diálogo Judicial no Ius COMMUNE LATINO-AMERICANO: COERÊNCIA, COESÃo E CONFORMAÇão CONSTITUCIONAL 314

Paulo Brasil Menezes

4. Diálogo ENTRE ORDENS INTERNACIONAIS E NACIONAIS: O CONSTITUCIONALISMO TRANSFORMADOR NA AMÉRICA LATINA

DIÁLOGO, INTERAMERICANIZACIÓN E IMPULSO TRANSFORMADOR: LOS FORMANTES TEÓRICOS DEL Ius Constitutionale Commune en América Latina ...............................................338 Mario Molina Hernández

O controle de convencionalidade pela Corte Interamericana de Direitos Humanos 364

Danilo Garnica Simini e José Blanes Sala

Controle legislativo DE CONVENCIONALIDADE DAS LEIS: A OPORTUNIDADE DE CONSTRUÇÃo do Ius Constitutionale Commune latino-americano pela Comissão de Constituição, Justiça e Cidadania da Câmara dos Deputados. .384

Ana Carolina Barbosa Pereira

A progressiva superaÇão da regulação do crime de desacato na América Latina: DIÁLOGOS ENTRE O DOMÉSTICO E O INTERNACIONAL .426 Luiz Guilherme Arcaro Conci e Melina Girardi Fachin

A interpretação do Sistema Interamericano de Direitos Humanos acerca da LIBERDADE DE EXPRESSÃo E A ADEQUAÇÃo MATERIAL DA LEI N. ${ }^{\circ} 13.834 / 2019$ 457 Elder Maia Goltzman e Mônica Teresa Costa Sousa

CAMINHOS LATINO-AMERICANOS A INSPIRAR A JURISDIÇÃo CONSTITUCIONAL BRASILEIRA NO DIÁLOGO MULTINÍVEL DO CONSTITUCIONALISMO REGIONAL TRANSFORMADOR .476 Rafael Osvaldo Machado Moura e Claudia Maria Barbosa

IUS CONSTITUTIONALE COMMUNE E DIREITO DE FAMÍlIA: UMA ANÁLISE HERMENÊUTICA DA jurisprudência da Corte Interamericana de Direitos Humanos e do Supremo Tribunal 
FEDERAL NA MATÉria

Felipe Frank e Lucas Miguel Gonçalves Bugalski

JusticiabilidAde DiRETA dos DiREITOS SOCIAIS NA CORTE INTERAMERICANA DE DIREITOS HUMANOS: MAIS UMA PEÇA NO QUEBRA-CABEÇA DO IUS CONSTITUTIONALE COMMUNE LATINOAMERICANO?.

Wellington Boigues Corbalan Tebar e Fernando de Brito Alves

5. DiÁlogo ENTRE ORDENS INTERNACIONAIS: O CONSTITUCIONALISMO TRANSFORMADOR ENTRE REGIÕES.

LA JURISPRUDENCIA EN EL DERECHO INTERNACIONAL GENERAL Y EL VALOR E IMPACTO DE LA jurisprudencia de la Corte Interamericana de Derechos Humanos y el Tribunal Europeo de Derechos Humanos..................................................................5545 Humberto Nogueira Alcalá

Diálogos À deriva: o Caso Lucien IKIli Rashidi c. República Unida da Tanzânia e outros e o esvaziamento da Corte Africana...........................................................568

Marcus Vinicius Porcaro Nunes Schubert e Catarina Mendes Valente Ramos

II. Parte especial

6. Povos indígenas E TRANSFORMAÇão

Hermenéuticas del derecho humano a la identidad CUltural EN La JURisprudencia INTERAMERICANA, UN ANÁLISIS COMPARADO A LA LUZ DEL ICCAL. .593 Juan Jorge Faundes e Paloma Buendía Molina

Ius Constitutionale Commune e O DiReito INdígena bRasileiro: os IMPaCtos da DeCisÃo do caso Povo Xukuru versus Brasil na jurisprudênCia e na administração pública NACIONAL

Flavianne Fernanda Bitencourt Nóbrega, Maria Eduarda Matos de Paffer e Anne Heloise Barbosa do Nascimento

Os PRECEDENTES dA CORTE INTERAMERICANA DE DIREITOS HUMANOS SOBRE TERRAS INDÍGENAS E A ADOÇÃO DA TEORIA DO INDIGENATO. 648

Eduardo Augusto Salomão Cambi, Elisângela Padilha e Pedro Gustavo Mantoan Rorato

7. Grupos VULNERÁVEIS E TRANSFORMAÇão

Ius Constitucionale Commune na América Latina: a Corte Interamericana de Direitos Humanos COMO INSTRUMENTO DE FIXAÇÃo DE STANDARDS PROTETIVOS AOS DiREITOS

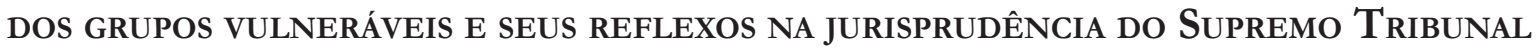
FEDERAL .666 Mônia Clarissa Hennig Leal e Eliziane Fardin de Vargas 
A eficácia da norma que ousou falar seu nome: os Princípios de Yogyakarta como potênCia densificadora do Ius Constitutionale Commune na América Latina .........687

Tiago Benício Trentini e Luiz Magno Bastos Jr

A Corte Interamericana de direitos humanos e a proteção dos direitos LGBTI: construindo um Ius Constitutionale Commune baseado na diversidade

João Pedro Rodrigues Nascimento, Tiago Fuchs Marino e Luciani Coimbra de Carvalho

LA VIOLENCIA INTRAFAMILIAR EN CONTEXTOS DE COVID-19: REALIDADES DEL AMPARO INSTITUCIONAL A SUJETOS DE ESPECIAL PROTECCIÓN EN ESCENARIOS DE EMERGÊNCIA .737 Víctor Julián Moreno Mosquera, John Fernando Restrepo Tamayo e Olga Cecilia Restrepo-Yepes

O caso Vélez loor vs. Panamá da Corte Interamericana de Direitos Humanos como PARADIGMA PARA A CONSTRUÇÃO DE PARÂMETROS MIGRATÓRIOS LATINO-AMERICANOS .757 Tatiana de A. F. R. Cardoso Squeff e Bianca Guimarães Silva

Direitos HUMANOS E ESTADO DE COISAS INCONSTITUCIONAL: O TRANSCONSTITUCIONALISMO LATINO-AMERICANO NA ADPF No 347 .783

Maiquel Ângelo Dezordi Wermuth e André Giovane de Castro

Trabalho escravo contemporâneo: as contribuições do diálogo ENTRE o Sistema InTERAMERICANo de Direitos Humanos E O Brasil PARA O FORTALECIMENTo dA Dignidade DO TRABALHADOR

Emerson Victor Hugo Costa de Sá, Sílvia Maria da Silveira Loureiro e Jamilly Izabela de Brito Silva

8. Direitos humanos, EMPRESAS e transformaÇão

DiÁlOgos MULTIATOR PARA IMPLEMENTAÇÃO DOS STANDARDS INTERAMERICANOS SOBRE Pandemia e Direitos Humanos

Ana Carolina Lopes Olsen e Anna Luisa Walter Santana

O ENVOLVIMENTO DE EMPRESAS EM VIOLAÇÕES DE DIREITOS HUMANOS E OS IMPACTOS DAS DECISÕES DA CORTE INTERAMERICANA

Patricia Almeida de Moraes e Marcella Oldenburg Almeida Britto

III. OUTRAS PERSPECTIVAS SOBRE TRANSFORMAÇÃO

Pluralismo jurídico e democracia comunitária: Discussões teóricas Sobre DESCOLONIZAÇÃo CONSTITUCIONAL NA BOLÍVIA

Débora Ferrazzo e Antonio Carlos Wolkmer

INTERCULTURALIDADE, PLURINACIONALIDADE E PLURALISMO NAS CONSTITUIÇÕES DO EQUADOR E DA BOLÍVIA: EXPOENTES PRINCIPIOLÓGICOS DO ESTADO PLURINACIONAL .897 Denise Tatiane Girardon dos Santos 
IUS COMMUNE: ENTRE O PLURALISMO JURISDICIONAL DIALÓGICO E A ADOÇÃO DE NORMAS ALTERATIVAS .

Ana Maria D'Ávila Lopes 


\title{
A interpretação do Sistema Interamericano de Direitos Humanos acerca da liberdade de expressão e a adequação material da Lei $n .^{\circ}$ 13.834/2019*
}

\author{
The Interamerican Human Rights' System \\ interpretation on free speech and the \\ content suitability of Law 13.834/2019
}

\author{
Elder Maia Goltzman** \\ Mônica Teresa Costa Sousa***
}

\section{Resumo}

Este artigo tem como problemática de pesquisa averiguar a compatibilidade material do art. 326-A do Código Eleitoral, inserido pela Lei n. ${ }^{\circ}$ 13.834/2019, em cotejo com o art. 13 da Convenção Interamericana de Direitos Humanos, que trata da liberdade de expressão. Objetiva-se discorrer sobre o conceito e amplitude da liberdade de expressão, sobre a liberdade de expressão em relação ao Sistema Interamericano de Direitos Humanos e da adequação da criação de crimes para combater notícias falsas em contextos eleitorais. Adota-se como método de pesquisa o jurídico-descritivo, e, como técnicas de pesquisa, a bibliográfica e a documental. Conclui-se pela incompatibilidade material do delito e, consequentemente, sua inconvencionalidade.

Palavras-chave: Liberdade de expressão; Sistema Interamericano; Desinformação; Lei n. ${ }^{\circ}$ 13.834/2019.

* Recebido em: 03/05/2021. Aprovado em: 07/10/2021

** Mestrando em Direito e Instituições do Sistema de Justiça pela Universidade Federal do Maranhão. Pesquisador do Núcleo de Estudos em Direito Internacional e Desenvolvimento (NEDID/UFMA/CNPq). Técnico na Clínica de Direito Humanitário da UFRGS. Membro da Academia Brasileira de Direito Eleitoral e Político (ABRADEP).

E-mail: eldergoltzman89@gmail.com

*** Doutora em Direito (UFSC). Professora Associada na UFMA. Docente nos cursos de Mestrado em Direito (PPGDir/UFMA) e Cultura e Sociedade (PGCult/UFMA). Bolsista de Produtividade em Pesquisa (FAPEMA). Coordenadora do Núcleo de Estudos em Direito Internacional e Desenvolvimento (NEDID/ UFMA/CNPq). Professora visitante na Universidade de Valencia (Espanha).

E-mail: monica.teresa@ufma.br

\section{Abstract}

This paper has as its main research issue to investigate the material suitability of Law 13.834/2019, which inserted the article 326-A in the Brazilian Electoral Code, and the article 13 of the Interamerican Convention of $\mathrm{Hu}-$ man Rights, which deals with free speech. The objectives are to discuss free speech's meaning and reach, to discuss free speech within the Interamerican Human Rights system and to discuss the suitability of creating crimes to oppose disinformation in electoral contexts. The methodology used is juridic-descriptive and the research techniques used were bibliographic and documental. The conclusion is that Law 13.834/2019 is not suitable regarding free speech and, therefore, is considered inconventional.

Keywords: Free speech; Interamerican System; Disinformation; Law 13.834/2019. 


\section{Introdução}

A liberdade de expressão é um direito ligado ao funcionamento do Estado Democrático de Direito. Os cidadãos precisam expor seus pensamentos, opiniões, crenças, discordâncias e insatisfações na condução da coisa pública para que, face à diversidade de argumentos, as melhores decisões sejam tomadas pelos gestores.

$\mathrm{Na}$ América do Sul, esse direito tem maior relevância porque, nas últimas décadas, a região

esteve basicamente dominada por regimes militares, que levaram a cabo brutais repressões, com dezenas de milhares de desaparecidos, torturados e mortos, sob o pretexto de combater a 'subversão comunista' supostamente materializada em organizações guerrilheiras.

Nesse contexto, a Organização dos Estados Americanos (OEA) tem atuado na defesa e fortalecimento da liberdade de pensamento e opinião em seus países membros. A instituição possui relatórios e publicações periódicas que dão um panorama desse direito nos países que a integram.

Recentemente, o tema da liberdade de expressão retornou aos holofotes por conta das fake news. Com o pretexto de combater a proliferação de notícias falsas, sobretudo em contextos eleitorais, os legislativos nacionais aprovaram leis que podem representar risco ao debate de ideias ${ }^{2}$.

No Brasil, ao fim de 2019, foi publicada a Lei n. ${ }^{\circ} 13.834$ que criou o crime de denunciação caluniosa com finalidade eleitoral por meio da inserção do artigo 326-A no Código Eleitoral Brasileiro. O dispositivo comina pena de reclusão de dois a oito anos e multa àqueles que derem causa à instauração de investigação policial, de processo judicial, de investigação administrativa, de inquérito civil ou ação de improbidade administrativa, atribuindo a alguém a prática de crime ou ato infracional de que o sabe inocente, com finalidade eleitoral.

Todavia, o país ratificou a Convenção Interamericana de Direitos Humanos que consagra a liberdade de expressão em seu art. 13 e, por conta disso, deve ter cautela ao elaborar normas que limitem o mercado de ideias. Considerando a dicotomia entre necessidade de proteção da liberdade de expressão e combate à desinformação, este artigo tem por problema de pesquisa averiguar a conformação material ${ }^{3}$, ou não, da Lei n. ${ }^{\circ}$ 13.834/2019 quando cotejada com o art. 13 do Pacto de San José da Costa Rica.

Para tanto, adota-se como método de abordagem o jurídico-descritivo ${ }^{4}$, e como técnicas de pesquisa a bibliográfica e documental, especialmente as sentenças da Corte Interamericana de Direitos Humanos e as publicações oficiais da Comissão Interamericana de Direitos Humanos.

O trabalho foi dividido em três seções que correspondem aos seus objetivos. Inicialmente, discute-se o conceito e amplitude da liberdade de expressão. Adota-se como marco teórico as ideias de John Stuart Mill ${ }^{5}$. O segundo tópico discorre sobre a liberdade de pensamento dentro do Sistema Interamericano de Direitos Humanos. O terceiro tópico trata da desinformação (fake news) e da criminalização da liberdade de expressão como resposta ao problema das notícias falsas em contextos eleitorais. Nas considerações finais, conclui-se pela inadequação material do art. 326-A face ao art. 13 da Convenção.

\footnotetext{
COGGIOLA, Osvaldo. O ciclo militar na América do Sul. 2014. Disponível em: https://blogdaboitempo.com.br/2014/03/24/ociclo-militar-na-america-do-sul/ Acesso em: 01 dez. 2020.

2 O sítio eletrônico Poynter possui um gráfico que mapeia as diversas iniciativas tomadas pelos países para combater as fake news. A publicação está em inglês, apenas. Para consultá-la, acessar https://www.poynter.org/ifcn/anti-misinformation-actions/

3 Este trabalho, por investigar a adequação material do art. 326-A do Código Eleitoral ao direito da liberdade de expressão previsto no art. 13 da Convenção, tem por foco a questão da liberdade de pensamento dentro do Sistema Interamericano de Direitos Humanos.

4 GUSTIN, Miracy Barbosa de Sousa; DIAS, Maria Tereza Fonseca. (Re)Pensando a Pesquisa Jurídica. Belo Horizonte: Del Rey, 2015.

5 MILL, John Stuart. Sobre a liberdade. Rio de Janeiro: Nova Fronteira, 2011.
} 


\section{Reflexões sobre a liberdade de expressão}

A Constituição Federal e a Convenção Interamericana de Direitos Humanos ressalvam, já em seus preâmbulos, a importância da democracia para o Estado de Direito ${ }^{6}$. Noam Chomsky apresenta duas concepções diferentes para o termo democracia ${ }^{7}$, mas somente uma delas traduz o ideal democrático factual porque abarca a participação popular.

Para Chomsky ${ }^{8}$, há a democracia em que o povo dispõe de condições para participar ativamente na condução dos assuntos pessoais de que tenha interesse, além de dispor de canais de informação de maneira livre e acessível. Nessa concepção, o cidadão tem liberdade para vivenciar e influenciar a tomada de decisões públicas e, também, tem a seu alcance ferramentas que permitem seus posicionamentos estarem ancorados em dados e fundamentos de interesse coletivo.

Há, também, a democracia "que considera que o povo deve ser impedido de conduzir seus assuntos pessoais e os canais de informação devem ser estreita e rigidamente controlados" . A ideia de democracia, defendida pela Constituição e pela Convenção, está contida na primeira exposição de Chomsky ${ }^{10}$ e não pode ser efetivada sem que o cidadão tenha liberdade para expressar suas opiniões.

Leonardo Valles Bento ${ }^{11}$ aduz que o livre debate e a deliberação sobre assuntos de interesse público são pressupostos do próprio conceito de democracia. E isso acontece porque não se pode considerar a existência de um sistema democrático no silêncio. É necessária a participação dos indivíduos por meio da exposição de suas ideias e crenças. Não é sem razão que regimes ditatoriais instituem maneiras de censurar seus opositores ${ }^{12}$.

Por essa razão a liberdade de expressão é um direito basilar para os sistemas democráticos. Stuart Mill, no século XIX, debruçando-se sobre a problemática do livre discurso, defendeu a ampla liberdade do indivíduo de poder se expressar ${ }^{13}$, ainda que se tenha a certeza de que a opinião exarada é falsa, sendo este o marco teórico principal adotado nesta pesquisa.

Para Mill, quando se impede alguém de se expressar, com a justificativa de certeza da falsidade do argumento alheio, parte-se do princípio de que a certeza do silenciador é absoluta e infalível ${ }^{14}$. Ocorre que a falibilidade é uma característica do homem e, por consequência, não há como ter certeza acerca de qual parte no debate está equivocada.

$\mathrm{Na}$ ciência política a questão possui contornos de importância. Anthony Lewis relata que, periodicamente, os Estados Unidos da América são assolados pelo medo fruto de manipulação política ${ }^{15}$. Incutir medo no povo, segundo o autor, permite que os políticos justifiquem seus abusos, que passam a ser cometidos pelo bem dos americanos. Assim, confundidos pelo temor, os eleitores legitimam explicações que podem não se sustentar no futuro, tornando a verdade de outrora objeto de questionamentos.

\footnotetext{
$6 \mathrm{Na}$ convenção, os Estados signatários reafirmam "seu propósito de consolidar neste Continente, dentro do quadro das instituições democráticas, um regime de liberdade pessoal e de justiça social, fundado no respeito dos direitos essenciais do homem". A seu turno, o texto constitucional brasileiro de 1988 dispõe que a constituinte visa "instituir um Estado Democrático".

7 CHOMSKY, Noam. Mídia: propaganda política e manipulação. São Paulo: Martins Fontes, 2014.

8 CHOMSKY, Noam. Midia: propaganda política e manipulação. São Paulo: Martins Fontes, 2014.

9 CHOMSKY, Noam. Mídia: propaganda política e manipulação. São Paulo: Martins Fontes, 2014. p. 6.

10 CHOMSKY, Noam. Mídia: propaganda política e manipulação. São Paulo: Martins Fontes, 2014.

11 BENTO, Leonardo Valles. Parâmetros internacionais do direito à liberdade de expressão. Revista de Informação Legislativa, ano 53, n. 210, p. 93-115, abr./jun., 2016.

12 Carvalho explica que um dos pilares da ditadura militar brasileira (1964-1085) foi justamente a censura política à imprensa para silenciar publicações ou reportagens capazes de atingir autoridades ou estruturas governamentais. CARVALHO, Lucas Borges de. A censura política à imprensa na ditadura militar: fundamentos e controvérsias. Revista da Faculdade de Direito, Curitiba, v. 59, n. 1, p. 79-100, 2014.

13 MILL, John Stuart. Sobre a liberdade. Rio de Janeiro: Nova Fronteira, 2011.

14 MILL, John Stuart. Sobre a liberdade. Rio de Janeiro: Nova Fronteira, 2011.

15 LEWIS, Anthony. Freedom for the thought that we hate: a biography of the first amendment. New York: Basic Books, 2009.
} 
Mill, desenvolvendo sua teoria, questiona as certezas absolutas dos indivíduos ${ }^{16}$, uma vez que, ainda que as pessoas ouçam vozes com argumentos dissidentes dos seus, apenas colocam confiança nas opiniões partilhadas com pessoas ao seu redor. O círculo próximo representa o "mundo" de certezas infalíveis de cada um.

[...] para cada indivíduo, o mundo é aquela parte do mundo com a qual ele entra em contacto; o seu partido, a sua seita, a sua igreja, a sua classe social: quase pode dizer-se que a pessoa para o qual o mundo é algo tão abrangente como o seu próprio país ou a sua própria época é, por comparação, liberal e tem vistas largas. E a sua confiança nesta autoridade coletiva não é de modo algum abalada por ter consciência de que outras eras, países, seitas, igrejas, grupos e partidos pensaram, e mesmo agora pensam, de modo exatamente oposto. Ela transfere para o seu próprio mundo a responsabilidade de ter a certeza, por oposição aos mundos discordantes de outras pessoas; e nunca a preocupa que um mero acaso tenha estabelecido qual destes muitos mundos seja alvo da sua confiança, e que as mesmas causas que fizeram dela um padre em Londres a teriam feito budista ou confucionista em Pequim ${ }^{17}$.

Em tempos de redes sociais e internet, quando as interações e busca de informações passam pelo espaço virtual, a formação das certezas absolutas, que antes eram consolidadas pelo círculo próximo, passa a ser determinada por algoritmos que trazem apenas aquilo que o usuário deseja ver; trata-se da filtragem, que consiste na escolha feita pelas plataformas em apenas trazer para o indivíduo conteúdos que tenham relação com seus acessos. Com isso, o indivíduo começa a viver numa bolha e suas informações não serão diversificadas, mas sim customizadas e relacionadas com algo que mantenha seu interesse ${ }^{18}$.

Dessa forma, se um sujeito se identifica com determinado espectro político e, por meio de suas mídias sociais, busca páginas ou informações que têm relação com suas convicções ou crenças, permanece em uma bolha informacional. $\mathrm{O}$ algoritmo da plataforma capta o interesse e oferece mais conteúdo similar ao acessado pelo indivíduo.

Tim Wu explica que isso acontece para que a atenção do usuário seja mantida na plataforma ${ }^{19}$. Assim, ela pode ser revendida pela empresa para anunciantes, por exemplo; o autor chama o fenômeno de Economia da Atenção porque o que está sendo vendido é a atenção de quem usa as redes. Disponibilizar àquele que acessa à internet algo que o desagrade tende a fazer com que ele fique menos tempo navegando.

Como os sujeitos, por meio dessas redes, veem apenas aquilo que se relaciona com seus acessos, suas crenças se tornam mais polarizadas e acirradas diante de discursos diversos dos seus, colaborando para o isolamento das pessoas que não sabem lidar com quem delas discorda ${ }^{20}$. O mundo externo passa a ser um ambiente de iguais. Pensamentos dissonantes são evitados porque incomodam o interlocutor que deixou de se acostumar a ouvir pensamentos que destoam dos seus, já que na internet tende a encontrar pessoas que pensam igual ${ }^{21}$.

O espaço de debate na esfera pública, conceituada por Habermas como "um domínio de nossa vida social em que algo que se aproxima da opinião pública pode ser formado"22, resta prejudicado diante do isolamento das pessoas que ficam cheias de certezas e creem em suas verdades. Não existe contraditório,

\footnotetext{
16 MILL, John Stuart. Sobre a liberdade. Rio de Janeiro: Nova Fronteira, 2011.

17 MILL, John Stuart. Sobre a liberdade. Rio de Janeiro: Nova Fronteira, 2011. p. 31.

18 SUNSTEIN, Cass. As mídias sociais são boas ou ruins para democracia? Revista Internacional de Direitos Humanos, v. 15, n. 27, p. 85-92, 2018.

19 TIM, Wu. Is the First Amendment obsolete? Michigan Law Review, v. 117, p. 2018. p. 547.

20 SUNSTEIN, Cass. REPUBLIC.COM. Nova Jersey: Princeton University Press, 2001.

21 Corre-se até mesmo o risco de a interação ser artificial diante da existência de bots. Em linhas simples, bots são robôs que conseguem interagir nas mídias sociais como se fossem humanos. No Twitter, por exemplo, existem ferramentas que identificam se determinado perfil é humano ou não. Para maiores informações: INSTITUTO DE TECNOLOGIA E SOCIEDADE DO RIO. PegaBot: descubra se aquele perfil de rede social é bot: plataforma em fase de testes. Disponível em: https://itsrio.org/pt/projetos/ pegabot/ Acesso em: 20 maio 2020.

22 HABERMAS, Jürgen. The public sphere: an encyclopedia article (1964). New German Critique, n. 3, p. 49-55, 1974. p. 49. Tradução nossa.
} 
tampouco confronto. O cidadão é exposto a uma linearidade de pensamento.

Ocorre que a verdade também é um conceito indeterminado e, por isso mesmo, pode ser adulterado mediante justificativas que dissimulem a culpa. Keyes afirma que se vive na hora da pós-verdade hoje justamente pela facilidade de os indivíduos modificarem a racionalidade dos fatos para que se encaixe em suas crenças $^{23}$.

Um exemplo é a suposta fragilidade do processo eletrônico de votação no Brasil. Embora não haja evidências ou provas de fraude, alguns brasileiros têm a crença sedimentada de que a urna eletrônica é objeto de falsificações a respeito da apuração dos votos. Por isso, ao encontrar qualquer notícia ou elemento que embase uma crença pré-concebida, ainda que não seja verdadeira, os sujeitos criam mecanismos internos que justificam e racionalizam a mentira que se torna, ao fim, verdade ${ }^{24}$.

Mill, mesmo no século XIX, pregava que somente se pode saber sobre um assunto ouvindo todas as opiniões ao seu respeito, ainda que falsas ${ }^{25}$. O incômodo causado pela discordância deve ser suportado para que se chegue a uma conclusão refletida. Não é sem razão que, em um ambiente democrático, pensadores como o inglês entendem que alguns debates somente chegam ao público porque mentiras foram plantadas no seio da comunidade. No pleito brasileiro de 2018, por exemplo, muito se discutiu sobre gênero por conta do suposto kit gay que seria distribuído em escolas da rede público de ensino ${ }^{26}$.

Nigel Warburton afirma que para Mill era claro que, mesmo visões falsas, desempenham um papel relativo ao livre mercado de ideias ${ }^{27}$. Se aqueles que proferem ideias falsas são silenciados, corre-se o risco do conhecimento do indivíduo se tornar dogmático; corre-se o risco de acreditar sem entender as razões que balizam aquela crença ou acreditar apenas em evidências que suportem aquilo que se tem por verdade.

Para Mill, sem que seja dada a garantia da liberdade de expressão, a verdade não terá como se afirmar, mesmo que, com isso, corra-se o risco de a verdade sucumbir em face da mentira ${ }^{28}$. Aline Osório pondera que, em certos momentos históricos, o pensador inglês reconhece que a mentira prevaleceu, mas ele defende que, mesmo assim, deve-se correr o risco ${ }^{29}$.

A igreja mais intolerante, a Igreja Católica, mesmo na canonização de um santo aceita um "advogado do diabo" e escuta-o pacientemente. Parece que não podem ser concedidas honras póstumas mais santa dentre as pessoas até se conhecer e levar em consideração tudo o que o diabo pudesse dizer contra ela. Se não fosse permitido que até mesmo a filosofia newtoniana fosse questionada, as pessoas não sentiriam uma tão completa certeza da sua verdade como agora sentem. As nossas crenças mais justificadas não têm qualquer outra garantia ${ }^{30}$.

Além disso, por ser um animal, o homem estaria sujeito a erros não somente oriundos do intelecto, mas também dos seus instintos ${ }^{31}$. Essa dupla possibilidade de falhar e se afastar do que é verdadeiro sem perceber que está incorrendo em erro revela-se como mais um fundamento para que discursos falsos sejam tolerados.

\footnotetext{
23 KEYES, Ralph. The Post-truth Era: dishonesty and deception in contemporary life. New York: Saint Martin's Press, 2004.

24 Como exemplo, citam-se os vídeos que circulam no WhatsApp e Youtube e que são desmentidos pela imprensa, como este: PARREIRA, Marcelo. É \#FAKE que vídeo prove que é possível fraudar urna eletrônica. G1, 2020. Disponível em: https:// g1.globo.com/fato-ou-fake/noticia/2020/11/18/e-fake-que-video-prove-que-e-possivel-fraudar-urna-eletronica.ghtml Acesso em: 20 maio 2020.

25 MILL, John Stuart. Sobre a liberdade. Rio de Janeiro: Nova Fronteira, 2011.

26 A questão está resumida nesta reportagem: É \#FAKE que Haddad criou «kit gay» para crianças de seis anos. G1, 2018. Disponível em: https://g1.globo.com/fato-ou-fake/noticia/2018/10/16/e-fake-que-haddad-criou-kit-gay-para-criancas-de-seis-anos. ghtml Acesso em: 20 maio 2020; O Tribunal Superior Eleitoral, inclusive, determinou a remoção de conteúdo dessa natureza. Para maiores informações acessar: https:/ /www.conjur.com.br/2018-out-16/ministro-tse-determina-remocao-videos-kit-gay.

27 WARBURTON, Nigel. Free Speech: a very short introduction. Oxford: Oxford University Press, 2009.

28 MILL, John Stuart. Sobre a liberdade. Rio de Janeiro: Nova Fronteira, 2011.

29 OSÓRIO, Aline. Direito eleitoral e liberdade de expressão. Belo Horizonte: Fórum, 2017.

30 MILL, John Stuart. Sobre a liberdade. Rio de Janeiro: Nova Fronteira, 2011. p. 33-34.

31 MILL, John Stuart. O utilitarismo. São Paulo: Iluminuras, 2020.
} 
Se temos instintos intelectuais que nos levam a julgar de um modo particular, assim como instintos animais que nos incitam a agir de um modo particular, não há necessidade alguma de que os primeiros sejam mais infalíveis na sua esfera do que os segundos na sua: pode bem ocorrer que juízos errados sejam, ocasionalmente, sugeridos pelos instintos intelectuais, assim como ações erradas pelos instintos animais ${ }^{32}$.

\section{Liberdade de expressão no Sistema Interamericano de Direitos Humanos}

A respeito do Sistema Interamericano de Direitos Humanos, a liberdade de expressão é celebrada e as limitações são vistas com cautelas, especialmente em países com história recente de ditaduras ${ }^{33}$.

O arcabouço normativo da liberdade de expressão é o art. 13 da Convenção Interamericana de Direitos Humanos, o qual assevera que:

Toda pessoa tem direito à liberdade de pensamento e de expressão. Esse direito compreende a liberdade de buscar, receber e difundir informações e ideias de toda natureza, sem consideração de fronteiras, verbalmente ou por escrito, ou em forma impressa ou artística, ou por qualquer outro processo de sua escolha.

Nesse sentido, a "censura prévia, leis de desacato e responsabilidade subsequente excessiva por injúria, calúnia e difamação são medidas que seriamente infringem a liberdade de expressão" 34 . O sentido da norma é permitir que os cidadãos possam participar da vida política do Estado de que fazem parte sem medo de represálias e sem uso da máquina pública para perseguição de opositores.

Claudio Grossman explica que a liberdade de expressão, na jurisprudência da Corte, tem caráter dual ${ }^{35}$. Envolve o direito de os indivíduos se expressarem e também o direito de receberem informações e ideias.

A Comissão Interamericana de Direitos Humanos, a seu turno, explana que a liberdade de expressão tem três dimensões principais em relação aos sistemas democráticos. A primeira diz respeito ao direito de pensar por si próprio e compartilhar as ideias com os demais ${ }^{36}$. Abarca, portanto, não somente o direito de pensamento consoante suas próprias convicções, mas, sobretudo, a garantia de poder disseminar junto aos demais suas crenças.

A segunda dimensão da liberdade de expressão tem relação estrutural com a democracia, sendo considerada pela Comissão o propósito, o motivo de existir do art. 13 da Convenção Interamericana de Direitos Humanos e se refere à proteção e promoção da livre circulação de informações, ideias e expressões de todos os tipos ${ }^{37}$. Para a Comissão:

o completo exercício do direito de expressar suas próprias ideias e opiniões, e de circular toda informação disponível, bem como a possibilidade de deliberação de forma aberta e sem censura sobre problemas que dizem respeito a todos é uma condição indispensável para a consolidação, funcionamento e preservação

\footnotetext{
32 MILL, John Stuart. O utilitarismo. São Paulo: Iluminuras, 2020. p. 85.

33 GROSSMAN, Claudio. Freedom of expression in the Interamerican System for the Protection of Human Rights. ILSA Journal of International and Comparative Law, v. 7, 2001.

34 GROSSMAN, Claudio. Freedom of expression in the Interamerican System for the Protection of Human Rights. ILSA Journal of International and Comparative Law, v. 7, 2001. p. 621. Tradução nossa.

35 GROSSMAN, Claudio. Freedom of expression in the Interamerican System for the Protection of Human Rights. ILSA Journal of International and Comparative Law, v. 7, 2001.

36 INTER-AMERICAN COMMISSION ON HUMAN RIGHTS. Inter-American Legal Framework. Organization of American States, 2009.

37 INTER-AMERICAN COMMISSION ON HUMAN RIGHTS. Inter-American Legal Framework. Organization of American States, 2009.
} 
dos regimes democráticos ${ }^{38}$.

O escopo da liberdade é impedir a censura que mina o funcionamento das democracias. A censura acaba por aumentar o poder do Estado de forma que os discursos que transitam na esfera pública precisariam de chancela de agentes públicos. Todavia, não raro, aqueles que exercem atividades públicas são objeto de críticas por sua atuação.

Lewis rememora que, na Inglaterra do século XVI, o Rei Henrique VIII somente permitia a impressão de quaisquer escritos que tivesse sido previamente autorizado, mesmo que se tratasse de um panfleto ou da escala de chegada e partida dos navios ${ }^{39}$. O sistema de licenciamento cerceava opiniões não ortodoxas em relação ao reinado.

A terceira dimensão refere-se à ligação da liberdade de expressão com o exercício de outros direitos. Sem liberdade de expressão, não haveria exercício pleno dos direitos de associação, liberdade religiosa, educação, identidade cultural e étnica e igualdade ${ }^{40}$.

Nesse ponto, o direito de poder se expressar configura um instrumento de efetivação de outros direitos. Sem ele, por exemplo, a liberdade religiosa estaria prejudicada porque os indivíduos teriam de professar sua fé ocultamente. A expressão artística, de semelhante modo, poderia estar sujeita ao crivo de terceiros. As associações necessitariam de autorizações do governo para instalação e funcionamento.

As restrições à liberdade de expressão, sobretudo as de caráter criminal, como lembra Bento, preocupam por seu efeito de autocensura nas pessoas ${ }^{41}$. Os cidadãos, temendo reprimendas penais por parte do Estado, deixam de emitir sua opinião e se afastam do debate público.

Sunstein, na mesma toada, assevera que é provável que a criminalização de condutas, relacionadas à liberdade de expressão, censure o aparecimento de narrativas verdadeiras por incutir medo nas pessoas ${ }^{42}$. Além disso, o julgamento do que é verdadeiro ou falso sai da esfera pública e passa ser atribuição do Estado, dando mais poder sobre a vida dos cidadãos.

No contexto do processo eleitoral, a Comissão Interamericana de Direitos Humanos aponta que a liberdade de expressão ganha contornos especiais e qualquer restrição deve ser vista com cautela. A liberdade de opinião, durante as eleições, funciona como uma ferramenta para formar a opinião do eleitor; em prol do fortalecimento do debate político entre os participantes, além de possibilitar maior escrutínio sobre as plataformas dos candidatos ${ }^{43}$.

É importante ressaltar que a Corte tem indicado que os limites às críticas aos políticos são mais amplos que os relacionados com pessoas comuns, já que os candidatos se colocam à disposição para análise de suas palavras e ações tanto pela opinião pública quanto pela mídia, o que por si só demonstra um grau maior de dever de tolerância ${ }^{44}$.

O caso Herrera Ulloa vs. Costa Rica, sentenciado pela Corte Interamericana de Direitos Humanos em

\footnotetext{
38 INTER-AMERICAN COMMISSION ON HUMAN RIGHTS. Inter-American Legal Framework. Organization of American States, 2009. p. 3. Tradução nossa.

39 LEWIS, Anthony. Freedom for the thought that we hate: a biography of the first amendment. New York: Basic Books, 2009.

40 INTER-AMERICAN COMMISSION ON HUMAN RIGHTS. Inter-American Legal Framework. Organization of American States, 2009

41 BENTO, Leonardo Valles. Parâmetros internacionais do direito à liberdade de expressão. Revista de Informação Legislativa, ano 53 , n. 210, p. 93-115, abr./jun., 2016.

${ }^{42}$ SUNSTEIN, Cass. Falsehoods and the First Amendment. 2019. Disponível em: https://papers.ssrn.com/sol3/papers.cfm?abstract_ id=3426765 Acesso em: 05 maio 2020.

43 INTER-AMERICAN COMMISSION ON HUMAN RIGHTS. Inter-American Legal Framework. Organization of American States, 2009.

44 INTER-AMERICAN COMMISSION ON HUMAN RIGHTS. Inter-American Legal Framework. Organization of American States, 2009.
} 
dois de julho de 2004, denota como o sistema interpreta a liberdade de expressão no contexto americano ${ }^{45}$.

Em quatro oportunidades, no ano de 1995, o jornalista Herrea Ulhoa publicou, no periódico " $\mathrm{La} \mathrm{Na}$ ción", artigos que reproduziam reportagens da imprensa belga. Os escritos atribuíam ao diplomata Félix Przedborski, representante ad honorem da Costa Rica na Organização Internacional de Energia Atômica, o cometimento de ilícitos graves. Em um processo sem recursos, o escritor foi condenado por quatro delitos de difamação e recebeu como pena a cominação de multa. Além disso, foi determinada a publicação do dispositivo da sentença no jornal.

Por conta da condenação proferida pelo Judiciário costarriquenho, em março de 2001, uma denúncia foi apresentada à Comissão Interamericana de Direitos Humanos. Após averiguações, a Comissão, em outubro de 2002, concedeu dois meses para que a Costa Rica seguisse, dentre outras, as seguintes recomendações: tornasse, sem efeito, a sentença condenatória em desfavor do jornalista Herrera Ulhoa e do Jornal "La Nación”, retirasse o nome de Herrera do registro nacional de delinquentes e reparasse os prejuízos sofridos pelo escritor mediante pagamento de indenização.

Em decorrência da inércia do Estado da Costa Rica, a Comissão submeteu o caso à Corte Interamericana de Direitos Humanos que condenou o país com fundamento na violação da liberdade de expressão e das garantias judiciais conferidas pelo Pacto de San José da Costa Rica.

Dentre as sanções, destacam-se a concessão de prazo para que o Estado costa-riquenho adequasse sua legislação interna ao disposto no Pacto e o pagamento de indenização ao jornalista no valor de vinte mil dólares americanos, além de outra indenização na monta de dez mil dólares americanos pelos gastos que Herrera teve para defender seus direitos no sistema interamericano.

Paiva e Heemann, comentando o caso Herrera Ulloa vs. Costa Rica, ratificam a importância que a Corte dá ao direito de liberdade de expressão para a manutenção de uma sociedade democrática ${ }^{46}$.

No julgamento, a Corte, no parágrafo 116 da sentença, advertiu que, sem uma efetiva liberdade de expressão, materializada em todos os seus termos, a democracia se desvanece, o pluralismo e a tolerância começam a quebrar, os mecanismos de controle e denúncia do cidadão começam a se tornar inoperantes e, definitivamente, se começa a criar o campo fértil para que sistemas autoritários se enraízem na sociedade ${ }^{47}$.

No que tange à resposta de supostos abusos no uso da liberdade de expressão, a Corte foi enfática em dizer que a resposta não deve ser por meio do Direito Penal, mas por meio dos meios administrativos ou civis, uma vez que, além de extremamente gravoso, o Direito Penal deve ser utilizado em última instância.

Salientou, também, que aqueles que atuam em nome do Estado sofrem uma limitação em seus direitos ${ }^{48}$. Assim, a tutela da honra de servidores públicos e agentes políticos deve ser feita com cautela e não pode ser comparada com a defesa da honra de pessoas privadas. As questões públicas são de interesse coletivo e não se pode usar a máquina pública, com seu braço penal, para incutir medo em críticos ao regime vigente sob pena de malbaratamento da própria democracia.

Recentemente, a questão da criminalização de discursos tem sido objeto de debate em decorrência do fenômeno das notícias falsas ou fake news, ponto que será abordado agora nesta investigação.

\footnotetext{
45 CORTE INTERAMERICANA DE DIREITOS HUMANOS. Caso Herrera Ulloa vs. Costa Rica. 2004.

46 PAIVA, Caio Cezar; HEEMANN, Thimotie Aragon. Jurisprudência internacional de direitos humanos. 2. ed. Belo Horizonte: CEI, 2017.

47 CORTE INTERAMERICANA DE DIREITOS HUMANOS. Caso Herrera Ulloa vs. Costa Rica. 2004.

48 CORTE INTERAMERICANA DE DIREITOS HUMANOS. Caso Herrera Ulloa vs. Costa Rica. 2004.
} 


\section{Fake news, desinformação e a inconvencionalidade da Lei 13.834/2019}

O termo fake news foi eleito como o mais significativo do ano de 2017 pelo dicionário Collins ${ }^{49}$. No entanto, a fabricação de informação não é algo que surgiu na contemporaneidade.

Posetti e Matthews elaboraram uma linha do tempo com alguns dos mais significativos exemplos de notícias falsas na história da humanidade, começando com uma campanha iniciada por Otávio para acabar com a reputação de Marco Antônio, em Roma, e finalizando, em 2018, com um resumo das ações tomadas por diversos países para combater o fenômeno ${ }^{50}$.

Embora o uso das fake news não seja recente, somente agora surgiu a tecnologia para disseminá-la de maneira tão efetiva ${ }^{51}$. Mesmo os discursos falsos não sendo novidade no cenário político, as ferramentas atuais permitem que as informações circulem com uma velocidade maior que antes e atinjam um número indeterminável de pessoas.

A definição do que seja fake news tem sido objeto de amplo debate. Katsirea ressalta que "uma definição precisa do termo 'fake news' é essencial se alguém quiser conseguir distinguir este fenômeno de outras formas de informações imprecisas, bem como de notícias verdadeiras".

Contudo, antes mesmo de estabelecer um conceito, é preciso reconhecer o que não seja enquadrado como fake news. No entendimento de Irini Katsirea, não se encaixam no conceito de notícia falsa ${ }^{52}$ : erros presentes em publicações, histórias tendenciosas, teorias da conspiração (que são difíceis de provar serem verdadeiras ou falsas, mas se originam de quem nelas acreditam) e frases imprecisas (sem que estejam em forma de notícias).

A sátira, igualmente, não é entendida como fake news. A intenção do autor nesse tipo de publicação é ridicularizar, usar do humor de maneira hiperbólica para chamar atenção a determinado ponto de vista, expor situações tidas por absurdas, ironizar. O escritor não tem a intenção de enganar seu leitor. No Brasil, há, como maiores expoentes, os sítios Sensacionalista e The Piauí Herald.

Trazendo uma definição sobre o que se entende por fake newss, em fevereiro de 2019, foi elaborado relatório final pelo Comitê Digital, Cultura, Mídia e Esporte, da Casa dos Comuns do Parlamento Britânico, em um inquérito que durou cerca de 18 meses e investigou a questão no Reino Unido ${ }^{53}$.

O Comitê concluiu que a expressão fake news assumiu muitas formas, sendo usada, inclusive, em situações em que o leitor, simplesmente, não gostou ou não concordou com o que viu. Assim, como maneira de promover uma visão mais ampla e segura, o Comitê sugeriu o uso das expressões misinformation e disinformation que, nesta pesquisa, serão traduzidas como informação falsa e desinformação, respectivamente ${ }^{54}$.

Para o Comitê, a diferença reside na intenção do agente. Se, desde o início, havia o dolo de criar ou compartilhar informações manipuladas, com o fito de enganar ou confundir o público, seja para causar dano ou por motivos políticos, financeiros ou pessoais, tem-se um caso de desinformação. Por outro lado, se o in-

\footnotetext{
49 FLOOD, Alisson. Fake news is 'very real' word of the year for 2017. Disponível em: https://www.theguardian.com/books/2017/ nov/02/fake-news-is-very-real-word-of-the-year-for-2017 Acesso em: 18 maio 2020.

50 POSETTI, Julie; MATTHEWS, Alice. A short guide to the history of 'fake news' and disinformation. New York: International Center for Journalists, 2018.

51 NOUGAYREDE, Natalie. In this age of propaganda, we must defend ourselves. Here's how. The Guardian, 2018. Disponível em: https://www.theguardian.com/commentisfree/2018/jan/31/propaganda-defend-russia-technology Acesso em: 12 out. 2019.

52 KATSIREA, Irini. "Fake news": reconsidering the value of untruthful expression in the face of regulatory uncertainty. Journal of Media Law, v. 10, n. 2, p. 159-188, 2018.

53 DIGITAL, CULTURE, MEDIA AND SPORT COMMITTEE. Disinformation and 'fake news': final report. Disponível em: https://publications.parliament.uk/pa/cm201719/cmselect/cmcumeds/1791/1791.pdf Acesso em: 12 out. 2019.

54 DIGITAL, CULTURE, MEDIA AND SPORT COMMITTEE. Disinformation and 'fake news': final report. Disponível em: https://publications.parliament.uk/pa/cm201719/cmselect/cmcumeds/1791/1791.pdf Acesso em: 12 out. 2019.
} 
divíduo compartilhou sem o intento de prejudicar, mas por crença no conteúdo, tem-se informação falsa ${ }^{55}$.

Wardle e Derakhshan trazem uma terceira categoria: mal-information, traduzida, neste artigo, como má-informaçã ${ }^{56}$. Diferentemente dos outros tipos, que tratam de informações inverídicas, a má-informação versa sobre situações reais que são trazidas à tona para prejudicar uma organização, pessoa ou país. Como exemplo, cita-se o caso da orientação sexual de um agente público que é mencionada em relatório sem que haja interesse público. A UNESCO também trabalha com essas três categorias ${ }^{57}$.

Este artigo adota o termo desinformação para abarcar todas as espécies de notícias acima mencionadas porque elas, em alguma medida, prejudicam o sistema democrático e o exercício do voto, tendo sido utilizadas em vários regimes políticos brasileiros ${ }^{58}$. Dada a imprecisão do termo fake news, que acabou sendo utilizado como forma de defesa por parte de agentes que, ao terem informações contra seus interesses, divulgadas, assim as taxavam, este artigo adota o termo desinformação por sua acuidade.

A Organização dos Estados Americanos visitou o Brasil no ano de 2018, durante as eleições gerais, por meio da Missão de Observação Eleitoral (MOE), e constatou que o uso de notícias falsas foi constante durante a fase pré-eleitoral e se estendeu até o dia do pleito, com intensificação no segundo turno ${ }^{59}$.

O cenário do uso alarmante de notícias falsas requer atenção especial de diversos atores estatais para proteger o sistema democrático e o exercício do direito ao voto de maneira livre, sem pressões ou influências oriundas de agentes maliciosos que buscam desequilibrar o pleito ou manchar reputações. Todavia, qualquer regulamentação ou ação por parte do Estado deve respeitar os direitos humanos e compromissos assumidos pelo Brasil diante dos entes internacionais, em especial a Organização dos Estados Americanos. Utilizando-se o argumento de impedir a proliferação da desinformação, pode-se minar a liberdade de expressão ${ }^{60}$.

Alguns países estão em um estágio inicial no enfrentamento de questões relacionadas a notícias falsas e desinformação. Para outros, a desinformação tem sido uma luta longa e o aspecto digital apenas traz uma nova dimensão. Há muito que existe tensão entre o desejo de permitir que a liberdade de expressão floresça e, mesmo em um contexto democrático ocidental fora dos EUA, o desejo de conter as formas mais indesejáveis de expressão em torno do terrorismo e do ódio. O momento para os governos agirem para combater notícias falsas e desinformação está agora se traduzindo em ações práticas, muitas das quais poderiam legitimar as ações de nações não democráticas e prejudicar a liberdade de expressão ${ }^{61}$.

Flávia Piovesan pontua que a América Latina apresenta elevado grau de violência e exclusão, tendo democracias ainda em fase de consolidação, convivendo com a lembrança de um passado ditatorial e precária tradição de respeito aos direitos humanos em âmbito interno, afirmando que:

O Sistema Interamericano tem a potencialidade de exercer um extraordinário impacto na pavimentação de um ius commune latino-americano, contribuindo para o fortalecimento dos direitos humanos, da democracia e do Estado de Direito na região mais desigual e violenta do mundo ${ }^{62}$.

\footnotetext{
55 DIGITAL, CULTURE, MEDIA AND SPORT COMMITTEE. Disinformation and 'fake news': final report. Disponível em: https://publications.parliament.uk/pa/cm201719/cmselect/cmcumeds/1791/1791.pdf Acesso em: 12 out. 2019.

56 WARDLE, Claire; DERAKHSHAN, Hossein. Information disorder: toward an interdisciplinary framework for research and policy making. 2017. Disponível em: https://rm.coe.int/information-disorder-toward-an-interdisciplinary-framework-forresearc/168076277c Acesso em: 05 maio 2020.

57 GRIZZLE, Alton et al. Alfabetização midiática e internacional: diretrizes para a formulação de políticas e estratégias. Brasília: UNESCO, 2016.

58 SILVA, Bruno Rangel Avelino da. Fake news, radiodifusão e os limites da Justiça Eleitoral. In: FUX, Luiz; PEREIRA, Luiz Fernando Casagrande; AGRA, Walber de MOURA (coord.); Propaganda eleitoral. Belo Horizonte: Fórum, 2018. p. 265-283.

59 ORGANIZAÇÃO DOS ESTADOS AMERICANOS. Missão de observação eleitoral: eleições gerais. 2018. Disponível em: http:// www.oas.org/documents/por/press/MOE-Brasil-2018-Relatorio-Final-POR.pdf Acesso em: 01 out. 2019.

${ }^{60}$ ORGANIZAÇÃO DOS ESTADOS AMERICANOS. Missão de observação eleitoral: eleições gerais. 2018. Disponível em: http:// www.oas.org/documents/por/press/MOE-Brasil-2018-Relatorio-Final-POR.pdf Acesso em: 01 out. 2019.

61 MORGAN, Susan. Fake news, disinformation, manipulation and online tactics to undermine democracy. Journal of Cyber Policy, v. 3, n. 1, p. 39-43, 2018. p. 42. Tradução nossa.

${ }^{62}$ PIOVESAN, Flávia. Sistema Interamericano de Direitos Humanos: impacto transformador, diálogos jurisdicionais e os desafios de reforma. Revista Direitos Emergentes na Sociedade Global, v. 3, n. 1, jan./jun., 2014. p. 100.
} 
O Sistema Interamericano desempenha importante papel na construção e manutenção da liberdade de expressão na América Latina. O art. 13 da Convenção Americana de Direitos Humanos é o regramento angular que norteia as decisões proferidas pela Corte.

Considerando-se a importância da liberdade de expressão para a manutenção da democracia, no relatório final pós eleição de 2018, a MOE recomendou ao Estado brasileiro a revogação dos crimes de desacato a autoridades, bem como a revogação dos tipos penais de calúnia, difamação e injúria e transformá-los em ações civis, com o devido respeito ao direito à liberdade de expressã $\mathrm{O}^{63}$. Ressalta-se que, ao tempo do relatório, não existia, no ordenamento nacional, a Lei 13.834/2019, que acrescentou o art. 326-A ao Código Eleitoral.

A referida norma, objeto de controvérsia no Brasil, foi vetada pelo Presidente Jair Bolsonaro, mas teve o veto derrubado pelo Congresso Nacional. $\mathrm{O}$ art. 326-A trouxe ao ordenamento jurídico brasileiro a figura da denunciação caluniosa com finalidade eleitoral. O dispositivo comina pena de reclusão de dois a oito anos, além de multa, a quem der causa à instauração de investigação policial, de processo judicial, de investigação administrativa, de inquérito civil ou ação de improbidade administrativa, atribuindo a alguém a prática de crime ou ato infracional de que o sabe inocente, com finalidade eleitoral.

Em relação ao delito recém inserido no ordenamento do Brasil paira dúvida acerca de sua convencionalidade, adotando-se como parâmetro de controle o art. 13 da Convenção Interamericana de Direitos Humanos e os precedentes da Corte Interamericana de Direitos Humanos.

Como apontado nos tópicos anteriores, a liberdade de expressão recebe atenção especial no contexto interamericano, especialmente pelo histórico de governos autoritários. As ditaduras brasileira e chilena são exemplos recentes na América do Sul quando se pensa em cerceamento da liberdade de expressão. Assim, qualquer limitação deve consubstanciar uma resposta estatal proporcional e adequada.

Sendo um direito sensível ligado ao funcionamento das estruturas democráticas do Estado, as intervenções, no discurso livre, devem ser pensadas de forma que os ganhos sejam maiores em comparação aos prejuízos. Assim é que "uma liberdade fundamental só pode ser limitada na medida em que sua restrição signifique a efetivação de outros direitos ou princípios" ${ }^{4}$ de igual ou maior envergadura. No caso da desinformação em contextos eleitorais, há outras alternativas viáveis que não a cominação de prisão.

A MOE, após o pleito de 2018, recomendou abordagem multissetorial (com autoridades, partidos políticos, membros da sociedade civil, meios de comunicação) e trabalho conjunto com universidades e organizações da sociedade civil para criar iniciativas participativas e transparentes que fomentem uma melhor compreensão do impacto que a desinformação tem sobre o processo eleitoral, assim como a formulação de respostas adequadas a esses fenômenos ${ }^{65}$.

A Justiça Eleitoral Brasileira, por meio do Tribunal Superior Eleitoral, atendendo os preceitos traçados pela missão, organizou seu Programa de Enfrentamento à Desinformação com Foco nas Eleições 2020 em 6 eixos temáticos, quais sejam: organização interna, Alfabetização Midiática e Informacional (AMI), contenção da desinformação, identificação e checagem de desinformação, aperfeiçoamento do ordenamento jurídico e aperfeiçoamento dos recursos tecnológicos ${ }^{66}$.

Justificando os pontos escolhidos, a corte pontua:

É preciso cautela redobrada para evitar que os próprios meios de enfrentamento à desinformação

\footnotetext{
63 ORGANIZAÇÃO DOS ESTADOS AMERICANOS. Missão de observação eleitoral: eleições gerais. 2018. Disponível em: http:// www.oas.org/documents/por/press/MOE-Brasil-2018-Relatorio-Final-POR.pdf Acesso em: 01 out. 2019.

${ }^{64}$ TÔRRES, Fernanda Carolina. O direito fundamental à liberdade de expressão. Revista de Informação Legislativa, Brasília, v. 50, n. 200, p. 61-80, out./dez., 2013. p. 70.

65 ORGANIZAÇÃO DOS ESTADOS AMERICANOS. Missão de observação eleitoral: eleições gerais. 2018. Disponível em: http:// www.oas.org/documents/por/press/MOE-Brasil-2018-Relatorio-Final-POR.pdf Acesso em: 01 out. 2019.

${ }_{66}$ BRASIL. Tribunal Superior Eleitoral. Programa de enfrentamento à desinformação com foco nas eleições 2020. 2020. Disponível em: https://www.justicaeleitoral.jus.br/desinformacao/arquivos/Programa_de_enfrentamento_web.pdf Acesso em: 07 ago. 2021.
} 
ocasionem limitações desproporcionais às liberdades de expressão, informação e imprensa, de modo a suprimir o "espaço de respiração" ("breathing space") necessário para que tais liberdades comunicativas possam florescer. Deve-se observar que algumas medidas ou respostas estatais — sobretudo quando mais abrangentes - podem levar à restrição de conteúdos relevantes ou promover o chamado "efeito resfriador" (chilling effect) do discurso, dissuadindo cidadãos e veículos de comunicação de se manifestarem, sob a ameaça da sanção ${ }^{67}$.

Borges e Sarmento explicam que, para o bom funcionamento de uma sociedade democrática, é necessário que haja uma esfera pública desinibida, em que as discussões de temas de interesse social ocorram sem medo de sanção ${ }^{68}$. Eventuais abusos devem ser tratados de forma restritiva sob pena de que responsabilizações, mormente as criminais, gerem um efeito resfriador (chilling effect ) nos cidadãos e na própria imprensa que, receosos de receber sanções estatais, preferem não opinar.

Na mesma linha, é preciso garantir espaços de respiração (breathing space) para o exercício dos discursos. Isto é, deve-se ter maior tolerância com os comportamentos e opiniões envolvidos no debate público sem que as ações gerem, em todos os casos, responsabilização dos participantes ${ }^{69}$.

Por essa razão, no pleito de 2020, um dos eixos escolhidos pelo TSE foi a alfabetização midiática e informacional. No contexto da liberdade de expressão, deve-se considerar que a "AMI é uma competência essencial na sociedade comunicativa de rápida evolução. Cidadãos alfabetizados em mídia e informação são pré-requisito para o vigor das sociedades do conhecimento inclusivas" ${ }^{30}$.

A alfabetização midiática e informacional representa um conjunto de atividades que busca capacitar o cidadão em várias frentes para que saiba utilizar as informações recebidas de maneira crítica e responsável. Destarte, a iniciativa da Justiça Eleitoral respeita os parâmetros traçados pela Organização dos Estados Americanos que desencoraja a criação de figuras típicas como forma de resposta ao fenômeno ${ }^{71}$.

A cominação de penas restritivas de liberdade, no contexto da desinformação, não respeita a subsidiariedade do braço penal do Estado. "O Direito Penal, devido à sua manifesta gravidade como instrumento estatal de contenção da liberdade do homem — apontada constantemente pela doutrina — deve ser sempre tido como subsidiário" 72 .

Além disso, existindo outros meios menos gravosos para lidar com a problemática, tal como a AMI, a existência do crime previsto no art. 326-A não sobrevive ao critério da razoabilidade e proporcionalidade em relação ao sacrifício desse direito fundamental que, segundo precedentes do Supremo Tribunal Federal, tem posição preferencial (preferred position) no ordenamento pátrio ${ }^{73}$.

A Comissão Interamericana de Direitos Humanos ressalta que a criação de figuras típicas como solução

67 BRASIL. Tribunal Superior Eleitoral. Programa de enfrentamento à desinformação com foco nas eleições 2020. 2020. Disponível em: https://www.justicaeleitoral.jus.br/desinformacao/arquivos/Programa_de_enfrentamento_web.pdf Acesso em: 07 ago. 2021.

68 BORGES, Ademar; SARMENTO, Daniel. Liberdade de expressão, crimes contra a honra de pessoa pública e o papel institucional da OAB: a inconstitucionalidade da denúncia contra Felipe Santa Cruz por críticas dirigidas a Sérgio Moro. Consultor Jurídico, 30 de janeiro de 2020. Disponível em: https://www.conjur.com.br/dl/santa-cruz-nao-cometeu-crime-criticar.pdf Acesso em: 07 mar. 2021.

69 BORGES, Ademar; SARMENTO, Daniel. Liberdade de expressão, crimes contra a honra de pessoa pública e o papel institucional da OAB: a inconstitucionalidade da denúncia contra Felipe Santa Cruz por críticas dirigidas a Sérgio Moro. Consultor Jurídico, 30 de janeiro de 2020. Disponível em: https://www.conjur.com.br/dl/santa-cruz-nao-cometeu-crime-criticar.pdf Acesso em: 07 mar. 2021.

70 GRIZZLE, Alton et al. Alfabetização midiática e internacional: diretrizes para a formulação de políticas e estratégias. Brasília: UNESCO, 2016. p. 8.

71 BRASIL. Tribunal Superior Eleitoral. Programa de enfrentamento à desinformação com foco nas eleições 2020. 2020. Disponível em: https://www.justicaeleitoral.jus.br/desinformacao/arquivos/Programa_de_enfrentamento_web.pdf Acesso em: 07 ago. 2021.

72 SANTOS, Marina O. T. A expansão do direito penal europeu frente à subsidiariedade da tutela penal: alternatividade a partir da Mediação Penal de Adultos portuguesa. Revista Brasileira de Direito Processual Penal, Porto Alegre, v. 5, n. 1, p. 219-251, jan./abr., 2019. p. 221.

73 V. ARE n. ${ }^{\circ}$ 719.618, rel. Min. Joaquim Barbosa, j. em 7.11.2012; Rcl n. ${ }^{\circ}$ 18.687 MC, rel. Min. Luís Roberto Barroso, j. em 27.9.2014; RE n. ${ }^{\circ}$ 685.493, rel. Min. Marco Aurélio; j. em 20.11.2014; Pet. n. ${ }^{\circ} 3.486$ rel. Min. Celso de Mello, j. em 22.8.2005. 
a crise causada pela desinformação em contextos eleitorais não encontra respaldo nos standards do Sistema Interamericano de Direitos Humanos. No atual estágio de compreensão de um fenômeno que é complexo e multifacetado, a introdução desses delitos nos sistemas legais poderá fazer com que a região retroaja a uma lógica de punir pessoas que critiquem servidores ou agentes envolvidos em assuntos de interesse coletivo ${ }^{74}$.

Nesse ponto, o art. 326-A falha por duas razões. Primeiro porque já existe a figura da denunciação caluniosa comum, prevista no art. 339 do Código Penal. Segundo porque, de acordo com o parágrafo primeiro, do art. 326-A, nas mesmas penas incorre quem, sabendo falsa a imputação, a propala ou divulga. Essa última parte do delito expressa risco ao cidadão comum e abre a possibilidade de uso da polícia e do aparato judiciário como forma de pressionar ou intimidar pessoas que pensam ou professam discursos diferentes de quem esteja figurando como detentor do poder.

Surge o temor de que, como contramedida, se procure responsabilizar alguém por denunciação caluniosa eleitoral a cada vez que oferecer notícia ou representação contra determinado políticos e candidatos. O crime de denunciação caluniosa, nesse caso, ao invés da proteção dos bens jurídicos, servirá como vendetta diante da perspectiva da investigação de fatos que podem ser graves. [...] Não teríamos incluído essa nova figura no Código Eleitoral. O rigor punitivo nela previsto destoa do conjunto dos crimes eleitorais, sem falar que esse intervalo de pena -2 a 8 anos - é muito largo. Oxalá o novo ilícito sirva para iluminar a urgente necessidade de reforma do sistema de crimes e penas eleitorais ${ }^{75}$.

Logo, a luta contra a desinformação pode e deve utilizar outras ferramentas que não sejam o direito penal e a instituição de figuras típicas que tragam riscos à participação popular e infrinjam compromissos assumidos pelo Brasil na Organização dos Estados Americanos.

É importante ressaltar que a "aplicação dos tratados e convenções internacionais de direitos humanos é temática recente no Brasil, restando muitas dúvidas quanto aos seus efeitos nos âmbitos jurídico e social”"76.

Entretanto, a novidade não pode ser entrave para a proteção dos direitos humanos, sobretudo porque o Brasil incorporou, definitivamente, a Convenção Interamericana de Direitos Humanos por meio do Decreto Presidencial n. ${ }^{\circ}$ 678/1992 e posterior aprovação do Congresso Nacional, confirmada pelo Decreto Legislativo n. ${ }^{\circ} 89 / 98^{77}$.

Não somente isso, o Brasil também já se expressou no sentido de reconhecer a "jurisdição obrigatória de órgãos internacionais, como a Corte Interamericana de Direitos Humanos, que têm como tarefa fixar a interpretação do alcance das obrigações internacionais de Direitos Humanos contraídas pelo Estado.”78

A Convenção Interamericana de Direitos Humanos tem status supralegal no ordenamento jurídico nacional, como decidido pelo Supremo Tribunal Federal nos Recursos Extraordinários 349.703 e 466.343 e Habeas Corpus 87.585 e $92.566^{79}$.

Mazzuoli pontua que as normas de um Estado não devem respeito, apenas, à Constituição, mas têm de estar em harmonia com a ordem jurídica internacional que integram sem que se observe violação de seus

\footnotetext{
74 COMISIÓN INTERAMERICANA DE DERECHOS HUMANOS. Guia para garantizar la libertad de expresión frente a la desinformación deliberada en contextos electorales. 2019. Disponível em: https://www.oas.org/es/cidh/expresion/publicaciones/Guia_Desinformacion_VF.pdf Acesso em: 03 fev. 2021.

75 GONÇALVES, Luiz Carlos dos Santos. O novo crime eleitoral: denunciação caluniosa. Revista da Escola Judiciária Eleitoral Paulista, n. 4, jan./jun. 2019. p. 11-12.

76 CHAVES, Denisson Gonçalves; SOUSA, Mônica Teresa Costa. O controle de convencionalidade e a autoanálise do judiciário brasileiro. Revista da Faculdade de Direito, Curitiba, v. 61, n. 1, p. 87-113, jan./abr., 2016. p. 88.

77 RAMOS, André de Carvalho. Supremo Tribunal Federal brasileiro e o controle de convencionalidade: levando a sério os tratados de direitos humanos. Revista da Faculdade de Direito da Universidade de São Paulo, v. 104, p. 241-286, jan./dez., 2009.

78 RAMOS, André de Carvalho. Supremo Tribunal Federal brasileiro e o controle de convencionalidade: levando a sério os tratados de direitos humanos. Revista da Faculdade de Direito da Universidade de São Paulo, v. 104, p. 241-286, jan./dez., 2009. p. 245.

79 Em síntese, a Suprema Corte decidiu que os tratados internacionais que versem sobre direitos humanos e que não tenham sido aprovados pelo rito especial do $\int 3^{\circ}$ do art. $5^{\circ}$ da Constituição Federal, ainda que anteriores ao rito (que foi inserido pela EC 45/2004), têm status supralegal. Isso quer dizer que os tratados que versem sobre direitos humanos estão acima da lei, mas abaixo da Constituição em hierarquia.
} 
preceitos $^{80}$; essa análise de respeito das normas internas aos tratados internacionais, que um dado país ratificou em seu ordenamento, se dá pelo controle de convencionalidade ${ }^{81}$.

Mazzuoli define controle de convencionalidade como a adequação vertical entre as normas domésticas em sentido lato vigentes no território nacional com os tratados internacionais ratificados pelo ente estatal ${ }^{82}$.

Russowsky chama atenção para os dois efeitos principais do controle de convencionalidade ${ }^{83}$. O primeiro, repressivo, significa que a norma conflituosa com as convenções vigentes não deve ser aplicada diante de casos concretos submetidos à apreciação judicial, o que classifica como controle difuso concreto de convencionalidade. $\mathrm{O}$ segundo efeito, positivo, refere-se à interpretação das normas. $\mathrm{O}$ direito nacional deve receber uma releitura à luz das convenções em vigência ${ }^{84}$. A interpretação da Lei 13.834/2019 não pode escapar dessa ótica.

Consoante apontado, em contraste com o disposto no art. 13 da Convenção Interamericana de Direitos Humanos, entende-se que o art. 326-A apresenta incompatibilidade material. Os principais fundamentos, elencados ao longo da investigação, foram: a criminalização de comportamentos relacionados à liberdade de ideias e pensamento não é defendida pelo Sistema Interamericano, seja em seus precedentes (caso Herrera, para citar um), seja em suas publicações oficiais (guias, relatórios e afins, todos referenciados ao final da pesquisa) ${ }^{85}$; há afronta ao mercado de ideias; existe o efeito censura e resfriador; tem-se a necessidade de espaços de respiração para que os discursos transitem; ocorre a possibilidade de sanção do cidadão que se envolve na crítica a agentes públicos; resulta o enfraquecimento do sistema democrático e, ainda, o histórico de abusos cometidos no continente americano.

Para além disso, há outras possibilidades menos gravosas ao debate público. Assim, a existência de um crime como resposta à desinformação em contextos eleitorais não respeita o caráter subsidiário que deve estar presente em uma norma penal incriminadora.

O TSE, em seus seis eixos de atuação no pleito de 2020, acabou por apontar caminhos que podem servir de parâmetro para a atuação do Estado brasileiro. A alfabetização midiática e informacional é um deles. No lugar de punir com ameaça de prisão quem participa do debate político, a AMI capacita o indivíduo para que seu olhar sobre o processo seja crítico e fundamentado. A corte explica que:

as ações dirigidas ao público externo priorizam aprendizagens voltadas ao conhecimento e à compreensão sobre desinformação; incentivo ao exercício de pensamento crítico diante de informações recebidas; incentivo à não reprodução de informações duvidosas; indicação de ferramentas e recursos de verificação de informações; conscientização sobre a importância dos dados pessoais; e informação sobre o processo eleitoral, em especial quanto ao funcionamento e à segurança das urnas eletrônicas ${ }^{86}$.

\footnotetext{
80 MAZZUOLI, Valério de Oliveira. Rumo às novas relações entre o direito internacional dos direitos bumanos e o direito interno: da exclusão à coexistência, da intransigência ao diálogo das fontes. 2008. Tese (Doutorado em Direito) - Universidade Federal do Rio Grande, Porto Alegre-RS, 2008.

81 Mazzuoli trata das distinções entre controle de constitucionalidade e controle de convencionalidade, bem como estuda os casos de conflito normativo entre disposições da Constituição e tratados. Contudo, esta pesquisa pontua tão somente a vinculação de uma norma infraconstitucional aos tratados internacionais ratificados pelos Estados por entender que a análise do conflito da Constituição com tratados deve se dar por meio de pesquisa específica que foge do escopo aqui em comento. MAZZUOLI, Valério de Oliveira. Rumo às novas relações entre o direito internacional dos direitos humanos e o direito interno: da exclusão à coexistência, da intransigência ao diálogo das fontes. 2008. Tese (Doutorado em Direito) - Universidade Federal do Rio Grande, Porto Alegre-RS, 2008.

82 MAZZUOLI, Valério de Oliveira. Rumo às novas relaçôs entre o direito internacional dos direitos humanos e o direito interno: da exclusão à coexistência, da intransigência ao diálogo das fontes. 2008. Tese (Doutorado em Direito) - Universidade Federal do Rio Grande, Porto Alegre-RS, 2008.

83 RUSSOWSKY, Iris Saraiva. O controle de convencionalidade das leis. Revista do CAAP, Belo Horizonte, v. 18, n. 2, p. 61-96, 2012.

${ }^{84}$ RUSSOWSKY, Iris Saraiva. O controle de convencionalidade das leis. Revista do CAAP, Belo Horizonte, v. 18, n. 2, p. 61-96, 2012.

85 Em declaração conjunta, tanto a Organização dos Estados Americanos, quanto a Organização das Nações Unidas e a Organização para Segurança e Cooperação na Europa defendem a premissa de que não se deve criminalizar a desinformação. Para acesso ao inteiro teor da nota: http://www.oas.org/es/cidh/expresion/showarticle.asp?artID=1174\&lID=2

86 BRASIL. Tribunal Superior Eleitoral. Programa de enfrentamento à desinformação com foco nas eleições 2020. 2020. p. 19. Disponível em: https://www.justicaeleitoral.jus.br/desinformacao/arquivos/Programa_de_enfrentamento_web.pdf Acesso em: 07 ago. 2021.
} 
Portanto, ao passo que o delito previsto, no art. 326-A do Código Eleitoral, distancia os eleitores da esfera pública de debate, a alfabetização midiática e informacional os aproxima e lhes habilita a fazerem escolhas conscientes e críticas num contexto de crise informacional.

\section{Considerações finais}

Embora o controle de convencionalidade não seja novidade no Brasil, as partes não têm o hábito de alegar disposições convencionais na defesa de seus direitos e o Judiciário não tem o costume de fundamentar suas decisões tomando por base tratados ou convenções visando sustentar a inconvencionalidade da legislação nacional.

Inclusive, não se tem notícia de qualquer alegação de incompatibilidade material entre o art. 13 da Convenção Interamericana de Direitos Humanos (que consagra a liberdade de opinião) e o crime de denúncia caluniosa com finalidade eleitoral introduzida no ordenamento brasileiro pela art. 326-A do Código Eleitoral.

A Lei 13.834/2019, com a justificativa de combater a desinformação em contexto eleitoral, acabou criando um crime desnecessário e inconvencional no ordenamento jurídico brasileiro.

Desnecessária porque a denunciação caluniosa comum, do art. 339 do Código Penal, de competência do Juiz de Direito ou Federal, a depender do caso, permitiria a investigação de qualquer pessoa que desse causa à instauração de investigação policial, de processo judicial, instauração de investigação administrativa, inquérito civil ou ação de improbidade administrativa contra alguém, imputando-lhe crime de que o sabe inocente, e sem qualquer relação com as eleições e a transição de poder, sendo um delito investigado fora do processo eleitoral.

Inconvencional porque, em contextos políticos, a liberdade de expressão somente pode ser limitada em casos excepcionais, e a Corte Interamericana de Direitos Humanos tem esse posicionamento firmado em suas sentenças. Quando uma pessoa decide concorrer a um mandato eletivo, deve ter ciência de que sua vida será escrutinada pela imprensa e população em geral. O candidato estará não somente sob os olhares do eleitorado, mas de outros interessados como servidores, aqueles que contratam com o poder público e áreas que podem ser atingidas por decisões tomadas pelo gestor público.

A liberdade de expressão não é um direito absoluto e que a honra das pessoas deve ser protegida de abusos. Todavia, deve-se ponderar, sim, que a liberdade de expressão, para a manutenção do Estado Democrático de Direito, tem uma posição de destaque se comparada com a honra ou a privacidade do candidato. Além disso, o candidato a cargo eletivo sabe que o jogo político, não de hoje, é permeado por desinformação.

Ressalta-se que não se defende que a desinformação nas eleições flua sem qualquer conduta do Estado. Ao contrário. O Estado deve agir, mas não por meio da criação de figuras típicas que não incentivam a participação democrática e, ainda, criam um efeito de autocensura no seio da sociedade. A denunciação caluniosa com finalidade eleitoral é um delito que tem potencial para impedir que o cidadão participe do espaço político por medo de represálias institucionalizadas.

Ora, criar um crime específico para tratar de questões que envolvem, num mesmo tipo, tanto a liberdade de expressão (denunciação caluniosa) como transição de poder por meio das eleições (com finalidade eleitoral), dois aspectos basilares do sistema democrático, não está de acordo com a proporcionalidade e adequação diante da pré-existência de um tipo semelhante (denunciação caluniosa do Código Penal) e de outras possibilidades não penais de lidar com o problema da desinformação.

Os limites que o ordenamento traz para a liberdade de pensamento devem ser justificados e razoáveis sob pena de esvaziamento de seu conteúdo paulatinamente. Mais que punir quem compartilha desinformação, a legislação deve olhar para os atores do processo eleitoral que ocorre no mundo digital: candidatos, 
mídias sociais e empresas de publicidade, por exemplo.

A desinformação tem uma origem e percorre um caminho, ambos devem ser analisados e desestimulados pela legislação, mas não por meio do Direito Penal. Candidatos mal-intencionados e outros interessados em desequilibrar o pleito dispõem de meios para apresentar defesa técnica em um processo penal por denunciação caluniosa eleitoral que pode se arrastar por anos. Em alguns casos, a legislação permite que o pagamento dos honorários dos patronos seja feito com recursos advindos do fundo partidário.

O cidadão comum, se acusado, e não dispondo de recursos para remunerar sua defesa, será assistido pela Defensoria Pública da União se estiver em uma área em que ela esteja instalada, o que acontece, geralmente, nas capitais. Nas zonas eleitorais do interior, a praxe é nomear um defensor dativo que, comumente, não tem experiência nas especificidades do processo penal eleitoral.

Assim, a defesa da liberdade de expressão, apresentada neste artigo, se fundamenta na inconvencionalidade do art. 326-A do Código Eleitoral, tomando-se por parâmetro o art. 13 da Convenção Interamericana de Direitos Humanos porque os prejuízos ao regime democrático superam os benefícios quando cotejados.

\section{Referências}

BENTO, Leonardo Valles. Parâmetros internacionais do direito à liberdade de expressão. Revista de Informação Legislativa, ano 53, n. 210, p. 93-115, abr./jun., 2016.

BORGES, Ademar; SARMENTO, Daniel. Liberdade de expressão, crimes contra a honra de pessoa pública e o papel institucional da OAB: a inconstitucionalidade da denúncia contra Felipe Santa Cruz por críticas dirigidas a Sérgio Moro. Consultor Jurídico, 30 de janeiro de 2020. Disponível em: https://www.conjur.com. $\mathrm{br} / \mathrm{dl} /$ santa-cruz-nao-cometeu-crime-criticar.pdf Acesso em: 07 mar. 2021.

BRASIL. Lei n. 13.834, de 4 de junho de 2019. Altera a Lei nº 4.737, de 15 de julho de 1965 - Código Eleitoral, para tipificar o crime de denunciação caluniosa com finalidade eleitoral. Disponível em: http:/ /www.planalto.gov.br/ccivil_03/_ato2019-2022/2019/lei/L13834.htm Acesso em: 07 ago. 2021.

BRASIL. Tribunal Superior Eleitoral. Programa de enfrentamento à desinformação com foco nas eleições 2020. 2020. Disponível em: https://www.justicaeleitoral.jus.br/desinformacao/arquivos/Programa_de_enfrentamento_web.pdf Acesso em: 07 ago. 2021.

CARVALHO, Lucas Borges de. A censura política à imprensa na ditadura militar: fundamentos e controvérsias. Revista da Faculdade de Direito, Curitiba, v. 59, n. 1, p. 79-100, 2014.

CHAVES, Denisson Gonçalves; SOUSA, Mônica Teresa Costa. O controle de convencionalidade e a autoanálise do judiciário brasileiro. Revista da Faculdade de Direito, Curitiba, v. 61, n. 1, p. 87-113, jan./abr., 2016.

CHOMSKY, Noam. Mídia: propaganda política e manipulação. São Paulo: Martins Fontes, 2014.

COGGIOLA, Osvaldo. O ciclo militar na América do Sul. 2014. Disponível em: https:/ /blogdaboitempo.com. br/2014/03/24/o-ciclo-militar-na-america-do-sul/ Acesso em: 01 dez. 2020.

COMISIÓN INTERAMERICANA DE DERECHOS HUMANOS. Guia para garantizar la libertad de expresión frente a la desinformación deliberada en contextos electorales. 2019. Disponível em: https://www.oas.org/es/ cidh/expresion/publicaciones/Guia_Desinformacion_VF.pdf Acesso em: 03 fev. 2021.

CORTE INTERAMERICANA DE DIREITOS HUMANOS. Caso Herrera Ulloa vs. Costa Rica. 2004.

DIGITAL, CULTURE, MEDIA AND SPORT COMMITTEE. Disinformation and 'fake news': final report. Disponível em: https://publications.parliament.uk/pa/cm201719/cmselect/cmcumeds/1791/1791. pdf Acesso em: 12 out. 2019. 
FLOOD, Alisson. Fake news is 'very real' word of the year for 2017. Disponível em: https://www.theguardian. com/books/2017/nov/02/fake-news-is-very-real-word-of-the-year-for-2017 Acesso em: 18 maio 2020.

GONÇALVES, Luiz Carlos dos Santos. O novo crime eleitoral: denunciação caluniosa. Revista da Escola Judiciária Eleitoral Paulista, n. 4, jan./jun. 2019.

GRIZZLE, Alton et al. Alfabetização midiática e internacional: diretrizes para a formulação de políticas e estratégias. Brasília: UNESCO, 2016.

GROSSMAN, Claudio. Freedom of expression in the Interamerican System for the Protection of Human Rights. ILS A Journal of International and Comparative Law, v. 7, 2001.

GUSTIN, Miracy Barbosa de Sousa; DIAS, Maria Tereza Fonseca. (Re)Pensando a Pesquisa Jurídica. Belo Horizonte: Del Rey, 2015.

HABERMAS, Jürgen. The public sphere: an encyclopedia article (1964). New German Critique, n. 3, p. 49-55, 1974.

INTER-AMERICAN COMMISSION ON HUMAN RIGHTS. Inter-American Legal Framework. Organization of American States, 2009.

KATSIREA, Irini. "Fake news": reconsidering the value of untruthful expression in the face of regulatory uncertainty. Journal of Media Law, v. 10, n. 2, p. 159-188, 2018.

KEYES, Ralph. The Post-truth Era: dishonesty and deception in contemporary life. New York: Saint Martin's Press, 2004.

LEWIS, Anthony. Freedom for the thought that we hate: a biography of the first amendment. New York: Basic Books, 2009.

MAZZUOLI, Valério de Oliveira. Rumo às novas relações entre o direito internacional dos direitos humanos e o direito interno: da exclusão à coexistência, da intransigência ao diálogo das fontes. 2008. Tese (Doutorado em Direito) - Universidade Federal do Rio Grande, Porto Alegre-RS, 2008.

MILL, John Stuart. O utilitarismo. São Paulo: Iluminuras, 2020.

MILL, John Stuart. Sobre a liberdade. Rio de Janeiro: Nova Fronteira, 2011.

MORGAN, Susan. Fake news, disinformation, manipulation and online tactics to undermine democracy. Journal of Cyber Policy, v. 3, n. 1, p. 39-43, 2018.

NOUGAYREDE, Natalie. In this age of propaganda, we must defend ourselves. Here's how. The Guardian, 2018. Disponível em: https://www.theguardian.com/commentisfree/2018/jan/31/propaganda-defend-russia-technology Acesso em: 12 out. 2019.

ORGANIZAÇÃO DOS ESTADOS AMERICANOS. Convenção Interamericana de Direitos Humanos. 1969. Disponível em: https://www.oas.org/pt/cidh/mandato/Basicos/convencion.asp Acesso em: 10 out. 2019.

ORGANIZAÇÃO DOS ESTADOS AMERICANOS. Missão de observação eleitoral: eleições gerais. 2018. Disponível em: http://www.oas.org/documents/por/press/MOE-Brasil-2018-Relatorio-Final-POR.pdf Acesso em: 01 out. 2019.

OSÓRIO, Aline. Direito eleitoral e liberdade de expressão. Belo Horizonte: Fórum, 2017.

PAIVA, Caio Cezar; HEEMANN, Thimotie Aragon. Jurisprudência internacional de direitos bumanos. 2. ed. Belo Horizonte: CEI, 2017.

PIOVESAN, Flávia. Sistema Interamericano de Direitos Humanos: impacto transformador, diálogos jurisdicionais e os desafios de reforma. Revista Direitos Emergentes na Sociedade Global, v. 3, n. 1, jan./jun., 2014. 
POSETTI, Julie; MATTHEWS, Alice. A short guide to the history of 'fake news' and disinformation. New York: International Center for Journalists, 2018.

RAMOS, André de Carvalho. Supremo Tribunal Federal brasileiro e o controle de convencionalidade: levando a sério os tratados de direitos humanos. Revista da Faculdade de Direito da Universidade de São Paulo, v. 104, p. 241-286, jan./dez., 2009.

RUSSOWSKY, Iris Saraiva. O controle de convencionalidade das leis. Revista do CAAP, Belo Horizonte, v. 18, n. 2, p. 61-96, 2012.

SANTOS, Marina O. T. A expansão do direito penal europeu frente à subsidiariedade da tutela penal: alternatividade a partir da Mediação Penal de Adultos portuguesa. Revista Brasileira de Direito Processual Penal, Porto Alegre, v. 5, n. 1, p. 219-251, jan./abr., 2019.

SILVA, Bruno Rangel Avelino da. Fake news, radiodifusão e os limites da Justiça Eleitoral. In: FUX, Luiz; PEREIRA, Luiz Fernando Casagrande; AGRA, Walber de MOURA (coord.); Propaganda eleitoral. Belo Horizonte: Fórum, 2018. p. 265-283.

SUNSTEIN, Cass. As mídias sociais são boas ou ruins para democracia? Revista Internacional de Direitos Humanos, v. 15, n. 27, p. 85-92, 2018.

SUNSTEIN, Cass. Falsehoods and the First Amendment. 2019. Disponível em: https://papers.ssrn.com/sol3/ papers.cfm?abstract_id=3426765 Acesso em: 05 maio 2020.

SUNSTEIN, Cass. REPUBLIC.COM. Nova Jersey: Princeton University Press, 2001.

TIM, Wu. Is the First Amendment obsolete? Michigan Law Review, v. 117, p. 2018.

TÔRRES, Fernanda Carolina. O direito fundamental à liberdade de expressão. Revista de Informação Legislativa, Brasília, v. 50, n. 200, p. 61-80, out./dez., 2013.

WARBURTON, Nigel. Free Speech: a very short introduction. Oxford: Oxford University Press, 2009.

WARDLE, Claire; DERAKHSHAN, Hossein. Information disorder: toward an interdisciplinary framework for research and policy making. 2017. Disponível em: https://rm.coe.int/information-disorder-toward-an-interdisciplinary-framework-for-researc/168076277c Acesso em: 05 maio 2020. 
Para publicar na revista Brasileira de Políticas Públicas, acesse o endereço eletrônico www.rbpp.uniceub.br

Observe as normas de publicação, para facilitar e agilizar o trabalho de edição. 